\title{
1 Attenuation by baclofen of nicotine rewarding properties and nicotine withdrawal 2 manifestations
}

4 Andrés P. Varani ${ }^{\mathrm{a}}$, Ester Aso ${ }^{\mathrm{b} \#}$, Lirane Machado Moutinho ${ }^{\mathrm{a}}$, Rafael Maldonado ${ }^{\mathrm{b}}$, Graciela N. Balerio ${ }^{\mathrm{ac}^{*}}$

${ }^{a}$ Instituto de Investigaciones Farmacológicas (CONICET), Junín $9565^{\circ}$ Piso, Buenos Aires C1113AAD, 7 Argentina.

${ }^{b}$ Laboratori de Neurofarmacologia, Facultat de Ciències de la Salut i de la Vida, Universitat Pompeu Fabra, C/Dr. Aiguader, 88, 08003 Barcelona, Spain.

${ }^{c}$ Cátedra de Farmacología, Facultad de Farmacia y Bioquímica, Universidad de Buenos Aires, Junín $9565^{\circ}$ Piso, Buenos Aires C1113AAD, Argentina.

"Present address: Institut de Neuropatologia, Servei d'Anatomia Patolòica, IDIBELL-Hospital Universitari de Bellvitge, L'Hospitalet de Llobregat, Spain

*Corresponding author. Dr. Graciela N. Balerio. Instituto de Investigaciones Farmacológicas (CONICET). Cátedra de Farmacología, Facultad de Farmacia y Bioquímica, Universidad de Buenos Aires, Junín $9565^{\circ}$ Piso, Buenos Aires C1113AAD, Argentina Tel.: +54-11-4961-5949. E-mail address: gbalerio@ffyb.uba.ar

\section{Acknowledgements}

This work has been supported by grants from University of Buenos Aires (UBACyT B016), CONICET (PIP 11420090100303), Spanish "Ministerio de Ciencia e Innovación" (\#SAF2011-29864), "Instituto de Salud Carlos III" (RETICS: \#RD06/0001/0001, \#RD06/0001/1004), Plan Nacional sobre Drogas (PNSD \#2009/026), the Catalan Government (SGR2009-00131) and the ICREA Foundation (ICREA Academia2008). Andrés P. Varani is a doctoral fellow of the University of Buenos Aires (677/10). The organizations have no further role in study design; in the collection, analysis and interpretation of the data; in the writing of the report; or in the decision to submit the paper for publication. The experiments comply with the current laws of the country in which they were performed. The authors declare they have no a financial relationship with the organizations that supported the research. 


\section{Abstract}

2 Rationale: Nicotine is a major active ingredient in tobacco and plays a major role in tobacco addiction. In

3 rodents, repeated nicotine administration produces behavioral responses related to its addictive properties,

$4 \quad$ such as reinforcing effects and physical dependence.

5 Objectives: The aim of the present study was to evaluate the possible role of $\mathrm{GABA}_{\mathrm{B}}$ receptor in responses

6 induced by repeated nicotine administration in Swiss Webster mice.

7 Results: Nicotine hydrogen tartrate salt $(0.5 \mathrm{mg} / \mathrm{kg}$, s.c.) administration induced rewarding properties in the 8 conditioning place preference test. The $\mathrm{GABA}_{\mathrm{B}}$ receptor agonist, baclofen ( $3 \mathrm{mg} / \mathrm{kg}$, i.p.) abolished the rewarding 9 properties induced by nicotine hydrogen tartrate salt $(0.5 \mathrm{mg} / \mathrm{kg}$, s.c.). In addition, naloxone-precipitated nicotine 10 withdrawal induced somatic manifestations, anxiety-like effects in the elevated plus maze test and dysphoric 11 manifestations in the conditioned place aversion paradigm. Baclofen ( 2 and $3 \mathrm{mg} / \mathrm{kg}$; i.p.) prevented the somatic 12 manifestations and the anxiety-like effects associated with naloxone-precipitated nicotine withdrawal but not the 13 dysphoric manifestations.

14 Conclusions: These results showed that nicotine rewarding properties and negative aspects of nicotine withdrawal, 15 such as anxiety-like effects and somatic manifestations, can be modulated by the GABA $\mathrm{B}_{\mathrm{B}}$ receptor activity. This 16 study now reveals a novel possible application of baclofen to develop new therapeutic strategies to achieve 17 smoking cessation.

21 Keywords: Nicotine, Baclofen, GABA ${ }_{B}$ receptors, Reward, Withdrawal, Mice. 


\section{Introduction}

2 Nicotine is a major active ingredient in tobacco smoke and plays a major role in tobacco addiction

3 (Stolerman and Jarvis, 1995). Nicotine produces its pharmacological responses by acting on nicotinic 4 acetylcholine receptors (nAChRs) that are mainly located at a presynaptic level (Dani 2001).

5 The activation of these receptors by nicotine increases the release of several neurotransmitters, including 6 dopamine, noradrenaline, serotonin, acetylcholine, glutamate and GABA (in Picciotto and Corrigall 2002).

7 The varied properties of the nAChRs can result in different patterns of neurotransmitter release following 8 acute and chronic nicotine administration, accounting for the complex behavioral effects of nicotine (in $9 \quad$ Picciotto et al. 2002).

10 People smoke to experience the psychoactive effects of nicotine, like mild euphoria, increased energy, 11 heightened arousal, reduced stress and anxiety and improve cognitive function, such as concentration, 12 reaction time and task performance (Pomerleau 1986; Gilbert et al., 1989). In rodents, acute nicotine 13 administration modifies a large number of physiological processes such as locomotion, nociception, anxiety,

14 learning and memory, as well as repeated nicotine administration produces several behavioral responses 15 directly related to its addictive properties, including rewarding effects and physical dependence (Decker 1995).

17 Preclinical studies support the idea that a number of GABAergic drugs, particularly the GABA $\mathrm{B}_{\mathrm{B}}$ receptor 18 agonist baclofen, decreases the abstinence signs from different drugs, such as ethanol (File et al. 1991), 19 barbitone (Sandoval and Palermo-Neto 1985) and morphine (Diaz et al. 2001). Baclofen also reduces 20 craving for several addictive drugs, including heroin, alcohol, and nicotine (Colombo et al. 2000; Corrigall 21 et al. 2000; Spano et al. 2007). In addition, baclofen antagonizes nicotine-, cocaine-, and morphine-induced 22 dopamine release in the nucleus accumbens (NAc) of rat (Fadda et al. 2003). Interestingly, baclofen prevents 23 nicotine rewarding properties in rats (Paterson et al. 2004; Le Foll et al. 2008) and the activation of GABA $A_{B}$ 24 receptor in the ventral tegmental area (VTA) attenuates the rewarding properties of psychostimulants and 25 nicotine (Cousins et al. 2002). Our laboratories have extensively explored the behavioral and neurochemical 26 effects of nicotine addiction. Indeed, we have previously observed an interaction between the GABAergic 27 and nicotinic cholinergic systems, given that baclofen prevented the somatic manifestation and 
1 neurochemical changes induced by mecamylamine-precipitated nicotine withdrawal in mice (Varani et al.

2 2011). On the other hand, the $\mathrm{GABA}_{\mathrm{B}}$ antagonist, 2-OH-saclofen, blocked the anxiolytic- and anxiogenic-

3 like effects induced by nicotine (Varani and Balerio 2012). Finally, we recently showed that acute

4 behavioral responses to nicotine (antinociception, hypolocomotion and anxiety-like effects) and nicotine

5 withdrawal syndrome are modified in $\mathrm{GABA}_{\mathrm{B} 1}$ knockout mice (Varani et al. 2012).

6 Taken together, these results suggest that several behavioral responses of nicotine related to its addictive

7 properties can be modulated through the activity of $\mathrm{GABA}_{\mathrm{B}}$ receptors. The aim of the present study was to 8 clarify the behavioral effects of baclofen on two important responses related to nicotine dependence: 9 nicotine rewarding properties and the emotional and somatic manifestation of nicotine withdrawal. Several 10 behavioral responses induced by repeated nicotine administration were evaluated in Swiss Webster mice 11 pretreated with baclofen. Nicotine reinforcing properties were investigated using the place preference 12 paradigm. In addition, the somatic manifestations and the anxiety-like effects induced by naloxone13 precipitated nicotine withdrawal were evaluated. Finally, the conditioned place aversion paradigm was used 14 to evaluate the aversive motivational state associated with nicotine withdrawal.

16 Materials and methods

17 Animals

18 Male Swiss Webster mice obtained from Bioterio Central (Facultad de Farmacia y Bioquímica, Universidad 19 de Buenos Aires, Argentina) weighing 22-24 g were housed five per cage, acclimated to the laboratory 20 conditions according to local regulation (SENASA, 2002) (12-h light: 12 -h dark cycle, $21 \pm 0.5^{\circ} \mathrm{C}$ room 21 temperature, $65 \pm 10 \%$ humidity) and manipulated for three days prior to the experiment for handling 22 habituation. Food and water were available ad libitum. Behavioral tests and animal care were conducted in 23 accordance with the standard ethical guidelines (European Community Guidelines on the Care and Use of 24 Laboratory Animals 86/609/EEC and 2001-486/EEC) and approved by the local ethical committee. All 25 experiments were performed with the investigators being blind to the treatment conditions. 
1 (-)-Nicotine hydrogen tartrate salt ([-]-1-methyl-2-[3-pyridyl]pyrrolidine), naloxone hydrochloride (Sigma-

2 Aldrich, USA) were dissolved in physiological saline $(0.9 \% \mathrm{NaCl})$ and administered by the subcutaneous

3 route. Nicotine doses used were calculated as nicotine hydrogen tartrate salt. ( \pm ) baclofen (Novartis, Basel,

4 Switzerland) was dissolved in physiological saline $(0.9 \% \mathrm{NaCl})$ and administered by intraperitoneal route.

5 Nicotine, naloxone and baclofen were administered in a volume of $10 \mathrm{~mL} / \mathrm{kg}$. Nicotine doses are reported as

6 nicotine hydrogen tartrate salt $(1 \mathrm{mg} / \mathrm{kg}$ of nicotine hydrogen tartrate salt equals to $0.35087 \mathrm{mg} / \mathrm{kg}$ nicotine 7 free base).

$9 \quad$ Place preference paradigm

10 In a different set of animals, the rewarding effects of nicotine hydrogen tartrate salt $(0.5 \mathrm{mg} / \mathrm{kg}, \mathrm{sc})$ were 11 evaluated by using the conditioned place preference paradigm, as previously described (Maldonado et al. 12 1997; Matthes et al. 1996). The apparatus consisted of two main square conditioning compartments 13 separated by a triangular central division. During the preconditioning phase, each mouse was placed in the 14 middle of the central division and had free access to both compartments of the conditioning apparatus for 18 15 min, with the time spent in each compartment recorded by computerized monitored software (Vision 16 Robot $^{\circledR}$, Argentina). Treatments were counterbalanced between compartments in order to use an unbiased 17 procedure. No initial place preference or aversion for the different compartments was observed in any of the 18 experiments. In the conditioning phase, saline and nicotine hydrogen tartrate salt conditioning sessions were 19 conducted daily over the next 4 days. Each day, animals were injected with saline and placed into 20 corresponding chamber for $20 \mathrm{~min}$. Four hours later, animals were injected with nicotine hydrogen tartrate 21 salt $(0.5 \mathrm{mg} / \mathrm{kg}$, s.c. $)$ and placed in the opposite chamber for $20 \mathrm{~min}$. Control animals received saline every 22 session in both chambers. The test phase was conducted exactly as for the pre-conditioning phase, i.e. free 23 access to both compartments during $18 \mathrm{~min}$, and the time spent in each compartment recorded. The time in 24 the central area was proportionally shared and added to the time value of each compartment as previously described (Maldonado et al. 1997; Valverde et al. 1996). A score value was calculated for each mouse as the difference between the time spent in the drug-paired compartment during the testing and pre-conditioning 
1 phases. Baclofen (1, 2 and $3 \mathrm{mg} / \mathrm{kg}$, i.p.) or vehicle was administered $45 \mathrm{~min}$ before nicotine injection during

2 the conditioning phase to evaluate their effect on the acquisition of the place preference.

$4 \quad$ Nicotine dependence and withdrawal

5 Induction of nicotine dependence

6 Mice were implanted subcutaneously with Alzet osmotic minipumps (Model, 2001) (Alzet ${ }^{\circledR}$, Cupertino, 7 CA), under brief diethyl ether anaesthesia. The minipumps contained saline or nicotine hydrogen tartrate salt 8 solutions and delivered a constant subcutaneous flow at a rate of $1 \mu \mathrm{L} / \mathrm{h}$. The concentration of nicotine 9 hydrogen tartrate salt was adjusted to compensate for differences in the body weight of the subjects. Thus, 10 average-weight mouse received a dose of approximately $25 \mathrm{mg} / \mathrm{kg} / \mathrm{day}$ nicotine hydrogen tartrate salt over 6 11 days. Two different set of mice were used to evaluate the somatic signs and the anxiety-like effects 12 associated with naloxone-precipitated nicotine withdrawal.

14 Naloxone-precipitated nicotine withdrawal: somatic signs

15 Nicotine withdrawal syndrome was precipitated 6 days after minipump implantation by injection of the $\mu-$ 16 opioid receptor antagonist naloxone (3 mg/kg, s.c.). The somatic signs of withdrawal were visually recorded 17 by one observer during a period of $15 \mathrm{~min}$ before and $30 \mathrm{~min}$ after naloxone injection, as previously reported 18 (Balerio et al. 2004). The number of wet dog shakes, front paw tremors, writhes and scratches was counted. 19 Body tremor, ptosis, teeth chattering, genital licks, and piloerection were scored 1 for appearance or 0 for 20 non-appearance within each $5 \mathrm{~min}$ time. The locomotor activity over 5 min periods was rated 0,1 , or $2(0$ 21 for inactivity, 1 for low activity, and 2 for normal activity). A global withdrawal score was calculated for 22 each animal by giving each individual sign a relative weight, as previously reported (Castañé et al. 2002). 23 Baclofen (1, 2 and $3 \mathrm{mg} / \mathrm{kg}$, i.p.) or vehicle were administered $45 \mathrm{~min}$ before naloxone injection.

25 Naloxone-precipitated nicotine withdrawal: anxiety-like effects

26 Other set of nicotine-dependent mice received a naloxone $(3 \mathrm{mg} / \mathrm{kg}$, s.c.) injection in order to precipitate the 27 nicotine withdrawal and were immediately placed in the elevated plus-maze test. The elevated plus-maze 
1 (Pellow et al., 1985; File et al., 1992) consisted of a black plastic apparatus with fours arms $(16 \times 5 \mathrm{~cm})$ set in

2 a cross from a neutral central square $(5 \times 5 \mathrm{~cm})$. Two opposite arms were delimited by vertical walls (closed

3 arms), while the other two opposite arms had unprotected edges (open arms). The maze was elevated $30 \mathrm{~cm}$

4 above the ground and illuminated from the top (100 lx). At the beginning of the 15-min observation session,

5 each mouse was placed in the central neutral area, facing one of the open arms. The total number of visits to

6 the closed and open arms, and the cumulative time spent in the open and closed arms were then observed on

7 a monitor through a video camera system (Vision Robot, Buenos Aires, Argentina). An arm visit was

8 recorded when the mouse moved both forepaws and the head into the arm, as we previously described

9 (Balerio et al. 2005). Baclofen (1, 2 and $3 \mathrm{mg} / \mathrm{kg}$, i.p.) or vehicle were administered 45 min before naloxone 10 injection.

12 Conditioned place aversion induced by naloxone-precipitated nicotine withdrawal

13 In a different set of animals, the place conditioning paradigm was used to evaluate the effect of baclofen (2 $14 \mathrm{mg} / \mathrm{kg}$ ) on the dysphoric manifestations associated with nicotine withdrawal. The apparatus consisted of two 15 main square conditioning compartments separated by a triangular neutral area (Maldonado et al. 1997). The 16 time spent by the mouse in each compartment was recorded by computerized monitoring software 17 (Videotrack $^{\circledR}$, View Point, France). In order to induce nicotine dependence in animals, mice were implanted 18 subcutaneously with osmotic minipumps (Alzet ${ }^{\circledR}$, Model 2002, Cupertino, CA) under brief diethyl ether 19 anaesthesia. The minipumps contained saline or nicotine hydrogen tartrate salt and delivered a constant flow 20 in a rate of $0.5 \mu \mathrm{L} / \mathrm{h}$. The concentration of nicotine will be adjusted to compensate for differences in the 21 body weight of the mice, and average-weight mouse received a dose of approximately $10 \mathrm{mg} / \mathrm{kg} / \mathrm{day}$ 22 nicotine hydrogen tartrate salt over 14 days. In the present study, naloxone $(0.12 \mathrm{mg} / \mathrm{kg}$, s.c. $)$ was used to 23 precipitate the aversive manifestations of nicotine withdrawal.

24 Five days after minipumps implantation, the pre-conditioning phase was performed. Each animal was placed in the neutral area, allowing to freely explore the conditioning compartments, and the time spent in each 26 compartment was recorded during $18 \mathrm{~min}$. Animals did not show any initial preference or aversion for the two compartments. Mice were distributed in the different treatment groups counterbalancing the drug-paired 
1 compartments. In the conditioning phase, animals received baclofen ( $2 \mathrm{mg} / \mathrm{kg}$, i.p.) or vehicle $45 \mathrm{~min}$ before

2 the withdrawal induction by the administration of naloxone $(0.12 \mathrm{mg} / \mathrm{kg}$, s.c. $)$ or saline (control group) on 3 days 7, 9, 11 and 13 after minipump implantation. Then, they were immediately confined in the withdrawal4 paired compartment by using guillotine doors matching walls for $30 \mathrm{~min}$. On days 8, 10, 12 and 14 after 5 minipump implantation, all mice received vehicle $45 \mathrm{~min}$ before saline injection, and were then immediately 6 confined in the saline-paired compartment for $30 \mathrm{~min}$. The post-conditioning phase was conducted on day 718 after minipump implantation, i.e., four days after the end of the nicotine infusions. This phase was 8 performed as the pre-conditioning phase, i.e., animals were placed in the neutral area and had free access to 9 the conditioning compartments during $18 \mathrm{~min}$. The time spent in the central area was proportionally 10 distributed and added to the time spent in each compartment, as previously reported (Maldonado et al. 11 1997). A score was calculated for each mouse as the difference between the post-conditioning and pre12 conditioning time spent in the drug-paired compartment.

14 Statistical analysis

15 The score values of nicotine place conditioning experiments, the somatic signs and the anxiety-like behavior 16 associated with nicotine withdrawal were analyzed using two-way ANOVA with chronic treatment (saline 17 or nicotine) and acute treatment (vehicle or baclofen) as between-subjects factors of variation, followed by 18 corresponding post-hoc test when appropriate (Fisher's test). For the place aversion conditioning 19 experiments, score values were compared using one way ANOVA for each chronic treatment (saline and 20 nicotine) followed by Fisher's post-hoc test.

22 Results

23 Baclofen blocked nicotine rewarding properties

24 We investigated the effect of baclofen $(1,2$ and $3 \mathrm{mg} / \mathrm{kg}$, ip) on the acquisition of nicotine hydrogen tartrate 25 salt $(0.5 \mathrm{mg} / \mathrm{kg}$, sc) rewarding properties in the place conditioning paradigm (Fig 1). Baclofen pre-treatment $26(3 \mathrm{mg} / \mathrm{kg})$ blocked the rewarding properties induced by nicotine (Fig. 4). Two-way ANOVA revealed a 27 significant effect of nicotine treatment $\left[\mathrm{F}_{(1,102)}=92.855, \mathrm{p}<0.001\right]$, baclofen pre-treatment $\left[\mathrm{F}_{(3,102)}=9.188\right.$, 
$1 \mathrm{p}<0.001]$ and interaction between these two factors $\left[\mathrm{F}_{(3,102)}=11.621, \mathrm{p}<0.001\right]$. Subsequent post-hoc (Fisher)

2 analysis revealed a significant effect of nicotine treatment in the vehicle $(\mathrm{p}<0.001)$ and baclofen $(1$ and 2

$3 \mathrm{mg} / \mathrm{kg})(\mathrm{p}<0.001)$ pre-treated mice, but not in those mice which were pre-treated with $3 \mathrm{mg} / \mathrm{kg}$ of baclofen.

4 Post-hoc also showed a significant blockade in the rewarding properties induced by nicotine in the baclofen $5 \quad(\mathrm{p}<0.001)(3 \mathrm{mg} / \mathrm{kg}$, ip) but not in the vehicle pre-treated animals (Fig. 1).

$7 \quad$ Baclofen prevented the somatic expression of nicotine withdrawal

8 The following somatic signs were significantly revealed in the different experimental groups: paw tremor, 9 body tremor, teeth chattering, genital licks, wet-dog shakes, scratches, ptosis, piloerection and locomotor 10 activity (see Table 1 for two-way ANOVA and Fisher's post-hoc test). Comparisons between saline and 11 nicotine treated groups receiving acute vehicle pre-treatment (Fisher's post-hoc test) showed that nicotine 12 withdrawal produced a significant incidence of paw tremor $(\mathrm{p}<0.001)$, body tremor $(\mathrm{p}<0.001)$, teeth 13 chattering $(\mathrm{p}<0.001)$ and wet-dog shakes $(\mathrm{p}<0.05)$ (Fig. 2$)$. In addition, baclofen $(3 \mathrm{mg} / \mathrm{kg})$ pre-treatment 14 significantly decreased paw tremor $(\mathrm{p}<0.001)$, body tremor $(\mathrm{p}<0.001)$, teeth chattering $(\mathrm{p}<0.001)$ and 15 wet-dog shakes $(\mathrm{p}<0.05)$ in nicotine withdrawal mice in comparison to mice pre-treated with vehicle (Fig. $162)$

17 The analysis of the global withdrawal score (see Table 1 for two-way ANOVA and Fisher's post-hoc test) 18 confirmed that baclofen $(3 \mathrm{mg} / \mathrm{kg})$ significantly prevented the severity of nicotine withdrawal. The severity

19 of nicotine withdrawal was significant in vehicle $(\mathrm{p}<0.001)$ but not in baclofen pre-treated mice, in 20 comparison to nondependent mice. In addition, the global withdrawal score was significantly reduced in 21 nicotine dependent mice pre-treated with baclofen $(3 \mathrm{mg} / \mathrm{kg})$ in comparison to those pre-treated with vehicle $22(\mathrm{p}<0.001)($ Fig. 2).

24 Baclofen prevented the anxiety-like effects associated with nicotine withdrawal

25 We investigated the effect of baclofen $(1,2$ and $3 \mathrm{mg} / \mathrm{kg})$ on anxiety-like behavior induced by naloxone26 precipitated nicotine withdrawal in the elevated plus maze test (Fig 3). Baclofen pre-treatment (3 mg/kg) 27 blocked the anxiety-like behavior induced by naloxone-precipitated nicotine withdrawal (Fig. 3). The two- 
way ANOVA revealed a significant effect of nicotine treatment $\left[\mathrm{F}_{(1,66)}=29.173, \mathrm{p}<0.001\right]$, baclofen pre-

2 treatment $\left[\mathrm{F}_{(3,66)}=9.409, \mathrm{p}<0.001\right]$ and interaction between these two factors $\left[\mathrm{F}_{(3,66)}=10.050, \mathrm{p}<0.001\right]$ for

3 the percentage of entries into the open arms. Comparisons between saline and nicotine treated groups

4 (Fisher's post-hoc test) showed that the percentage of entries into the open arms was significantly decreased

5 ( $\mathrm{p}<0.001)$ in mice receiving acute vehicle pre-treatment (Fig. 3A). In addition, the decreased percentage of

6 entries into the open arms induced by nicotine withdrawal was significantly prevented in baclofen (2 and 3

$7 \mathrm{mg} / \mathrm{kg})(\mathrm{p}<0.001)$ pre-treated mice, but not in those mice which were pre-treated with baclofen $1 \mathrm{mg} / \mathrm{kg}$

8 (Fig. 3A). On the other hand, two-way ANOVA revealed a significant effect of nicotine treatment

$9 \quad\left[\mathrm{~F}_{(1,66)}=25.549, \mathrm{p}<0.001\right]$, baclofen pre-treatment $\left[\mathrm{F}_{(3,66)}=5.321, \mathrm{p}<0.01\right]$ and interaction between these two

10 factors $\left[\mathrm{F}_{(3,66)}=5.869, \mathrm{p}<0.001\right]$ for the percentage of time spent in the open arms. Comparisons between

11 saline and nicotine treated groups (Fisher's post-hoc test) showed that the percentage of time spent in the

12 open arms was significantly decreased $(\mathrm{p}<0.001)$ in mice receiving acute vehicle pre-treatment $($ Fig. 3B). In

13 addition, the decreased percentage of time spent in the open arms induced by nicotine withdrawal was

14 significantly prevented in baclofen $(2 \mathrm{mg} / \mathrm{kg}, \mathrm{p}<0.05$ and $3 \mathrm{mg} / \mathrm{kg}, \mathrm{p}<0.001)$ pre-treated mice, but not in 15 those mice which were pre-treated with baclofen $1 \mathrm{mg} / \mathrm{kg}$ (Fig. 3B).

Baclofen did not modify the dysphoric manifestations of nicotine withdrawal

18 The effect of baclofen $(2 \mathrm{mg} / \mathrm{kg}$, i.p.) pre-treatment on the dysphoric manifestations of naloxone-precipitated

19 nicotine withdrawal was analyzed (Fig. 4). Time spent in the withdrawal paired compartment during pre-test

20 was similar in the different experimental groups, which ensures the use of an unbiased procedure (one-way ANOVA, $\left[\mathrm{F}_{(5,74)}=0.1243, \mathrm{p}=0.987\right]$, data not shown). No abnormal behavior was observed during the conditioning phase after the administration of naloxone $(0.12 \mathrm{mgkg})$. Fisher's post hoc test revealed a significant decrease in the score of vehicle and baclofen pre-treated nicotine-dependent animals conditioned to naloxone-precipitated withdrawal as compared to vehicle pre-treated nicotine-dependent animals conditioned with saline $(\mathrm{p}<0.05)$. No significant changes were observed when comparing vehicle or baclofen pre-treated mice, revealing that conditioned place aversion induced by naloxone in nicotine treated mice was not modified by baclofen pre-treatment (Fig. 4). 
2 Discussion

3 The effects of baclofen administration have been evaluated on the chronic effects of nicotine. Our results

4 demonstrate that acute baclofen administration prevented rewarding properties induced by nicotine.

5 Baclofen also prevented the somatic signs and anxiety-like effects, but not the dysphoric manifestations

6 associated with naloxone-precipitated nicotine withdrawal.

7 Acute rewarding effects of drugs of abuse are responsible for the initiation of the addictive process (in Koob 8 and Le Moal 2001). Nicotine acute rewarding properties were investigated in mice by using the place 9 conditioning paradigm. Nicotine hydrogen tartrate salt $(0.5 \mathrm{mg} / \mathrm{kg}$, s.c. $)$ induced a significant place 10 preference, as expected (Berrendero et al. 2002, 2005; Castañé et al. 2002, 2006; Trigo et al. 2009) and 11 baclofen did not produce any intrinsic response in this paradigm, in agreement with previous studies 12 (Heinrichs et al. 2010). In the present study, baclofen (3 mg/mg, i.p.) blocked the nicotine conditioned place 13 preference, suggesting that $\mathrm{GABA}_{\mathrm{B}}$ receptor activity would be involved in the rewarding effects of nicotine.

14 In agreement, baclofen prevents the nicotine rewarding properties in the place conditioning paradigm in rats 15 (Le Foll et al. 2008). Moreover, baclofen has been reported to reduce nicotine rewarding effects in the rat 16 self-administration paradigm (Corrigall et al. 2000; Fattore et al. 2002; Paterson et al. 2004). In addition, a 17 recent report showed that baclofen blocked the reinstatement of extinguished nicotine place preference in 18 mice (Fattore et al. 2009). Therefore, GABA G $_{B}$ receptor activation would modulate nicotine self19 administration, the reinstatement of extinguished nicotine place preference as well as the acquisition of 20 nicotine place preference in mice. The effect of baclofen here observed could be related to its capacity to 21 activate $\mathrm{GABA}_{\mathrm{B}}$ receptors located postsynaptically in dopaminergic neurons of the VTA (Laviolette and van 22 der Kooy 2004), causing a decrease of dopamine release in the NAc (Fadda et al. 2003), leading to the 23 blockade of nicotine rewarding effects (Cousins et al. 2002).

24 Importantly, acute baclofen administration prevented the somatic expression of naloxone-precipitated 25 nicotine withdrawal, as revealed by the significant decrease of relevant somatic signs, such as paw-tremors, 26 body tremor, teeth chattering and wet-dog-shakes. Nicotine dependence was induced by using minipumps 27 delivering a constant rate of nicotine hydrogen tartrate salt solution over a 6-day period and the $\mu$-opioid 
receptor antagonist naloxone (3 $\mathrm{mg} / \mathrm{kg}$, s.c.) precipitated a withdrawal syndrome, as previously reported

2 (Balerio et al. 2004; Biala et al. 2005). Naloxone did not modify somatic signs by itself, in agreement with 3 previous studies (Diaz et al. 2001; Luo et al. 2012; Mori et al. 2013), In addition, naloxone administration 4 has been widely used to precipitate withdrawal in nicotine-dependent rodents (Adams and Cicero 1998; 5 Carboni et al. 2000; Malin et al. 1993), and also induces somatic signs of nicotine withdrawal in chronic 6 smokers (Krishnan-Sarin et al. 1999), presumably by a possible blockade of nAChRs (Tome et al. 2001). 7 Conversely, human clinical trials showed that another opioid antagonist (naltrexone) decreases nicotine 8 withdrawal signs in chronic smokers (Epperson et al. 2010; Toll et al. 2010; King et al. 2012), which support 9 the possible effect of naloxone on nAChRs (Tome et al. 2001). Together, these effects reveal the role of the endogenous opioid system in nicotine abstinence (Houdi et al. 1998; Isola et al. 2002; Berrendero et al., 112002 , 2005). The present study revealed that baclofen pre-treatment prevented the somatic manifestations of 12 naloxone-precipitated nicotine withdrawal, suggesting that $\mathrm{GABA}_{\mathrm{B}}$ receptors would be involved in the 13 control of nicotine withdrawal signs. Similarly, we have previously shown that baclofen prevented the 14 somatic signs of nicotine withdrawal precipitated in mice by the selective nicotinic receptor antagonist 15 mecamylamine (Varani et al. 2011), and this nicotine withdrawal syndrome was abolished in $\mathrm{GABA}_{\mathrm{B} 1}$ 16 knockout mice (Varani et al. 2012). The effects of baclofen in preventing naloxone-precipitated nicotine 17 withdrawal signs were not due to changes in locomotion since no significant differences between saline18 saline and saline-baclofen groups were revealed (see table 1 for locomotor activity sign), in agreement with 19 previous studies (Diaz et al. 2001; Varani et al. 2011; Villas Boas et al. 2012). In addition, baclofen did not 20 induce motor incoordination or sedation, as confirmed by the rota-rod test (Balerio and Rubio 2002). 21 Therefore, our results suggest the involvement of $\mathrm{GABA}_{\mathrm{B}}$ receptors on naloxone-precipitated nicotine 22 withdrawal syndrome, which could imply the existence of a possible interaction between the opioid, 23 GABAergic and nicotine neurotransmitter systems (in Berrendero et al. 2010; Kenny and Markou 2001 and 24 Markou 2008). The prevention of nicotine withdrawal by baclofen here evidenced could be related to its ability to modulate opioid cells directly connected with dopaminergic in the striatum (Ma et al. 2012; Miura et al. 2007), a brain area involved in nicotine withdrawal expression (Natividad et al. 2010; Rada et al. 2001; Varani et al. 2011). However, further studies would be required to support this mechanistic explanation. 
1 Several studies in animals (Cheeta et al. 2001; Irvine et al. 2001) and humans (Parrott and Garnham 1998)

2 have revealed that nicotine withdrawal results in an increased anxiety-like effect, which has been proposed 3 as an affective aspect of nicotine withdrawal. Our results showed that naloxone-precipitated nicotine 4 withdrawal increased the anxiety-like effects in the elevated plus maze. Similarly, it has been reported that 5 mecamylamine-precipitated (Jackson et al. 2008; Rehni et al. 2012) or spontaneous nicotine withdrawal 6 induce a reduction in exploration of the open arms of the elevated plus maze in mice (Abreu-Villaça et al. 7 2008; Jackson et al. 2009; Manhães et al. 2008). Our results revealed that naloxone alone did not change the 8 elevated plus maze responses when compared to control mice, in accordance to previous reports (Hodgson et 9 al. 2008). Interestingly, baclofen pre-treatment prevented nicotine abstinence-induced anxiety-like effects on 10 the elevated plus maze test, without any intrinsic effect of baclofen on anxiety levels (Dalvi and Rodgers 11 1996; Varani and Balerio 2012). Therefore, our study revealed that the anxiety-like effects induced by 12 nicotine withdrawal could be pharmacologically minimized by the activation of GABA $\mathrm{B}_{\mathrm{B}}$ receptors. The 13 effects of baclofen in preventing the anxiety-like responses associated with naloxone-precipitated nicotine 14 withdrawal were not due to changes in locomotion since no significant differences were revealed on the 15 locomotor responses after the different treatments (see table 1 for locomotor activity sign).

16 Finally, the effects of baclofen pre-treatment were evaluated on the aversive manifestations associated with 17 nicotine withdrawal. The dose of baclofen $(2 \mathrm{mg} / \mathrm{kg})$ used in these set of experiments was selected taking 18 into account the results obtained in the experiments of somatic manifestations and the anxiety-like effects 19 associated to naloxone-precipitated nicotine withdrawal. The administration of naloxone precipitated 20 dysphoric manifestations of nicotine withdrawal in nicotine dependent mice, as previously described for 21 mice (Balerio et al. 2004) and rats (Ise et al. 2000; Watkins et al. 2000), indicating that the opioid system is 22 particularly important in the negative emotional states associated with nicotine withdrawal (in Kenny and 23 Markou 2001). In our experimental conditions, no somatic manifestations of nicotine withdrawal were 24 observed during the conditioning phase in mice receiving this low dose of naloxone $(0.12 \mathrm{mg} / \mathrm{kg}), \mathrm{in}$ agreement with previous studies (Balerio et al. 2004). These aversive manifestations of nicotine withdrawal were not modified by the pre-treatment with baclofen $(2 \mathrm{mg} / \mathrm{kg})$, which had no intrinsic effect as previously reported (Chester and Cunningham 1999). Therefore, the aversive states produced during naloxone- 
1 precipitated nicotine withdrawal cannot be modulated by the activation of $\mathrm{GABA}_{\mathrm{B}}$ receptors, at least in our

2 experimental conditions.

3 In conclusion, we provide herein pharmacological evidence of the specific involvement of $\mathrm{GABA}_{\mathrm{B}}$ receptors

4 in the regulation of rewarding properties induced by nicotine. Interestingly, the present results also indicate

5 that baclofen administration prevents the expression of somatic signs and the anxiety-like effects associated

6 with naloxone-precipitated nicotine withdrawal in mice, suggesting an interaction between the opioid,

7 GABAergic and cholinergic systems. The elucidation of this interaction provides a further step towards a

8 better understanding of the complex nicotine behavioral responses in mice. All together, these data underline

9 the interest of $\mathrm{GABA}_{\mathrm{B}}$ receptor as a potential target for the development of novel therapeutics approaches

10 for nicotine addiction (Markou et al. 2004; Franklin et al. 2009). In addition, based on the available

11 preclinical and clinical studies we suggested that baclofen could be a promising compound for the treatment

12 of nicotine addiction. This study now reveals a novel possible application of baclofen to develop new

13 therapeutic strategies to achieve smoking cessation.

14

15

16

17

18

19

20

21

22

23

24

25

26

27

28

29 
Abreu-Villaça Y, Nunes F, do E Queiroz-Gomes F, Manhães AC, Filgueiras CC (2008) Combined exposure to nicotine and ethanol in adolescent mice differentially affects anxiety levels during exposure, short-term, and long-term withdrawal. Neuropsychopharmacology 3(3):599-610.

Adams ML, Cicero TJ (1998) Nitric oxide mediates mecamylamine- and naloxone-precipitated nicotine withdrawal. Eur J Pharmacol 345(2):R1-2.

Balerio GN, Aso E, Berrendero F, Murtra P, Maldonado R (2004) Delta9-tetrahydrocannabinol decreases somatic and motivational manifestations of nicotine withdrawal in mice. Eur J Neurosci 20:2737-2748.

Balerio GN, Aso E, Maldonado R (2005) Involvement of the opioid system in the effects induced by nicotine on anxiety-like behaviour in mice. Psychopharmacology (Berl) 181:260-269.

Balerio GN, Rubio MC (2002) Baclofen analgesia: involvement of the GABAergic system. Pharmacol Res 46(3):281-286.

Berrendero F, Kieffer BL, Maldonado R (2002) Attenuation of nicotine-induced antinociception, rewarding effects, and dependence in mu-opioid receptor knock-out mice. J Neurosci 22(24):10935-10940.

Berrendero F, Mendizábal V, Robledo P, Galeote L, Bilkei-Gorzo A, Zimmer A, Maldonado R (2005) Nicotine-induced antinociception, rewarding effects, and physical dependence are decreased in mice lacking the preproenkephalin gene. J Neurosci 25(5):1103-1112.

Berrendero F, Robledo P, Trigo JM, Martín-García E, Maldonado R (2010) Neurobiological mechanisms involved in nicotine dependence and reward: participation of the endogenous opioid system. Neurosci Biobehav Rev 35(2):220-231.

Biała G, Budzyńska B, Kruk M (2005). Naloxone precipitates nicotine abstinence syndrome and attenuates nicotine-induced antinociception in mice. Pharmacol Rep 57(6):755-760.

Carboni E, Bortone L, Giua C, Di Chiara G (2000) Dissociation of physical abstinence signs from changes in extracellular dopamine in the nucleus accumbens and in the prefrontal cortex of nicotine dependent rats. Drug Alcohol Depend 58(1-2):93-102.

Castañé A, Soria G, Ledent C, Maldonado R, Valverde O (2006) Attenuation of nicotine-induced rewarding effects in A2A knockout mice. Neuropharmacology 51(3):631-40.

Castañé A, Valjent E, Ledent C, Parmentier M, Maldonado R, Valverde O (2002) Lack of CB1 cannabinoid receptors modifies nicotine behavioural responses, but not nicotine abstinence. Neuropharmacology 43:857867.

Cheeta S, Irvine EE, Kenny PJ, File SE (2001) The dorsal raphe nucleus is a crucial structure mediating nicotine's anxiolytic effects and the development of tolerance and withdrawal responses. Psychopharmacology 155:78-85.

Chester JA, Cunningham CL (1999) Baclofen alters ethanol-stimulated activity but not conditioned place preference or tasteaversion in mice. Pharmacol Biochem Behav 63(2):325-331.

Colombo G, Agabio R, Carai MA, Lobina C, Pani M, Reali R, Addolorato G, Gessa GL (2000) Ability of baclofen in reducing alcohol intake and withdrawal severity: I--Preclinical evidence. Alcohol Clin Exp Res 24(1):58-66. 
Corrigall WA, Coen KM, Adamson KL, Chow JZ (2000) Response of nicotine self-administration in the rat to manipulations of mu-opioid and $\gamma$-aminobutyric acid receptors in the ventral tegmental area. Psychopharmacology (Berl) 149:107-114.

Cousins MS, Roberts DC, de Wit $\mathrm{H}(2002) \mathrm{GABA}_{(\mathrm{B})}$ receptor agonists for the treatment of drug addiction: a review of recent findings. Drug Alcohol Depend. 65(3):209-220.

Dalvi A, Rodgers RJ (1996) GABAergic influences on plus-maze behavior in mice. Psychopharmacology (Berl) 128(4):380-397.

Dani JA (2001) Overview of nicotinic receptors and their roles in the central nervous system. Biol Psychiatry 49(3):166-174.

Decker MW, Brioni JD, Bannon AW, Arneric SP (1995) Diversity of neuronal nicotinic acetylcholine receptors: lessons from behaviour and implications for CNS therapeutics. Life Sci 56(8):545-570.

Diaz SL, Kemmling AK, Rubio MC, Balerio GN (2001) Lack of sex-related differences in the prevention by baclofen of the morphine withdrawal syndrome in mice. Behav Pharmacol 12:75-79.

Epperson CN, Toll B, Wu R, Amin Z, Czarkowski KA, Jatlow P, Mazure CM, O'Malley SS (2010) Exploring the impact of gender and reproductive status on outcomes in a randomized clinical trial of naltrexone augmentation of nicotine patch. Drug Alcohol Depend 112(1-2):1-8.

Fadda P, Scherma M, Fresu A, Collu M, Fratta W (2003) Baclofen antagonizes nicotine-, cocaine-, and morphine-induced dopamine release in the nucleus accumbens of rat. Synapse 50(1):1-6.

Fattore L, Cossu G, Martellotta MC, Fratta W (2002) Baclofen antagonizes intravenous self-administration of nicotine in mice and rats. Alcohol Alcohol 37(5):495-498.

Fattore L, Spano MS, Cossu G, Scherma M, Fratta W, Fadda P (2009) Baclofen prevents drug-induced reinstatement of extinguished nicotine-seeking behaviour and nicotine place preference in rodents. Eur Neuropsychopharmacol 19:487-498.

File SE, Andrews N, Wu PY, Zharkovsky A, Zangrossi H Jr (1992) Modification of chlordiazepoxide's behavioural and neurochemical effects by handling and plus-maze experience. Eur J Pharmacol 218:9-14.

File SE, Zharkovsky A, Gulati K (1991) Effects of baclofen and nitrendipine on ethanol withdrawal responses in the rat. Neuropharmacology 30(2):183-190.

Franklin TR, Harper D, Kampman K, Kildea-McCrea S, Jens W, Lynch KG, O'Brien CP, Childress AR (2009) The $\mathrm{GABA}_{\mathrm{B}}$ agonist baclofen reduces cigarette consumption in a preliminary double-blind placebocontrolled smoking reduction study. Drug Alcohol Depend 103(1-2):30-36.

Gilbert DG, Robinson JH, Chamberlin CL, Spielberger CD (1989) Effects of smoking/nicotine on anxiety, heart rate, and lateralization of EEG during a stressful movie. Psychophysiology 26(3):311-320.

Heinrichs SC, Leite-Morris KA, Carey RJ, Kaplan GB (2010) Baclofen enhances extinction of opiate conditioned place preference. Behav Brain Res 207(2):353-359.

Hodgson SR, Hofford RS, Norris CJ, Eitan S (2008) Increased elevated plus maze open-arm time in mice during naloxone-precipitated morphine withdrawal. Behav Pharmacol 19(8):805-811. 
Houdi AA, Dasgupta R, Kindy MS (1998) Effect of nicotine use and withdrawal on brain preproenkephalin A mRNA. Brain Res 799(2):257-63.

Irvine EE, Cheeta S, File SE (2001) Tolerance to nicotine's effects in the elevated plus-maze and increased anxiety during withdrawal. Pharmacol Biochem Behav 68:319-325.

Ise Y, Narita M, Nagase H, Suzuki T (2000) Modulation of opioidergic system on mecamylamineprecipitated nicotine-withdrawal aversion in rats. Psychopharmacology (Berl) 151(1):49-54.

Isola R, Zhang H, Duchemin AM, Tejwani GA, Neff NH, Hadjiconstantinou M (2002) Met-enkephalin and preproenkephalin mRNA changes in the striatum of the nicotine abstinence mouse. Neurosci Lett 325(1):6771.

Iwamoto ET (1991) Characterization of the antinociception induced by nicotine in the pedunculopontine tegmental nucleus and the nucleus raphe magnus. J Pharmacol Exp Ther 257:120-133.

Jackson KJ, Martin BR, Changeux JP, Damaj MI (2008) Differential role of nicotinic acetylcholine receptor subunits in physical and affective nicotine withdrawal signs. J Pharmacol Exp Ther 325(1):302-312.

Jackson KJ, McIntosh JM, Brunzell DH, Sanjakdar SS, Damaj MI (2009) The role of alpha6-containing nicotinic acetylcholine receptors in nicotine reward and withdrawal. J Pharmacol Exp Ther 331(2):547-554.

Kenny PJ, Markou A (2001) Neurobiology of the nicotine withdrawal syndrome. Pharmacol Biochem Behav 70(4):531-49.

King AC, Cao D, O'Malley SS, Kranzler HR, Cai X, deWit H, Matthews AK, Stachoviak RJ (2012) Effects of naltrexone on smoking cessation outcomes and weight gain in nicotine-dependent men and women. J Clin Psychopharmacol 32(5):630-636.

Koob GF, Le Moal M (2001) Drug addiction, dysregulation of reward, and allostasis. Neuropsychopharmacology 24(2):97-129.

Krishnan-Sarin S, Rosen MI, O'Malley SS (1999) Naloxone challenge in smokers. Preliminary evidence of an opioid component in nicotine dependence. Arch Gen Psychiatry 56(7):663-668.

Laviolette SR, van der Kooy D (2004) The neurobiology of nicotine addiction: bridging the gap from molecules to behaviour. Nature Reviews Neuroscience 5:55-65.

Le Foll B, Wertheim CE, Goldberg SR (2008) Effects of baclofen on conditioned rewarding and discriminative stimulus effects of nicotine in rats. Neurosci Lett 443(3):236-240.

Luo FC, Qi L, Lv T, Wang SD, Liu H, Nakamura H, Yodoi J, Bai J (2012) Geranylgeranylacetone protects mice against morphine-induced hyperlocomotion, rewarding effect, and withdrawal syndrome. Free Radic Biol Med 52(7):1218-1227.

Ma YY, Cepeda C, Chatta P, Franklin L, Evans CJ, Levine MS (2012) Regional and cell-type-specific effects of DAMGO on striatal D1 and D2 dopamine receptor-expressing medium-sized spiny neurons. ASN Neuro. doi: 10.1042/AN20110063

Maldonado R, Saiardi A, Valverde O, Samad TA, Roques BP, Borrelli E (1997) Absence of opiate rewarding effects in mice lacking dopamine D2 receptors. Nature 388(6642):586-589. 
Malin DH, Lake JR, Carter VA, Cunningham JS, Wilson OB (1993) Naloxone precipitates nicotine abstinence syndrome in the rat. Psychopharmacology 112:339-342.

Manhães AC, Guthierrez MC, Filgueiras CC, Abreu-Villaça Y (2008) Anxiety-like behavior during nicotine withdrawal predict subsequent nicotine consumption in adolescent C57BL/6 mice. Behav Brain Res 193(2):216-224.

Markou A (2008) Neurobiology of nicotine dependence. Philos Trans R Soc Lond B Biol Sci. 363(1507):3159-3168.

Markou A, Paterson NE, Semenova S (2004) Role of gamma-aminobutyric acid (GABA) and metabotropic glutamate receptors in nicotine reinforcement: potential pharmacotherapies for smoking cessation. Ann N Y Acad Sci 1025:491-503.

Matthes HW, Maldonado R, Simonin F, Valverde O, Slowe S, Kitchen I, Befort K, Dierich A, Le Meur M, Dollé P, Tzavara E, Hanoune J, Roques BP, Kieffer BL (1996) Loss of morphine-induced analgesia, reward effect and withdrawal symptoms in mice lacking the mu-opioid-receptor gene. Nature 383(6603):819-823.

Millar NS, Gotti C (2009) Diversity of vertebrate nicotinic acetylcholine receptors. Neuropharmacology $56: 237-246$.

Miura M, Saino-Saito S, Masuda M, Kobayashi K, Aosaki T (2007) Compartment-specific modulation of GABAergic synaptic transmission by mu-opioid receptor in the mouse striatum with green fluorescent protein-expressing dopamine islands. J Neurosci 27(36):9721-9728.

Mori T, Komiya S, Uzawa N, Inoue K, Itoh T, Aoki S, Shibasaki M, Suzuki T (2013) Involvement of supraspinal and peripheral naloxonazine-insensitive opioid receptor sites in the expression of $\mu$-opioid receptor agonist-induced physical dependence. Eur J Pharmacol 715(1-3):238-245.

Natividad LA, Tejeda HA, Torres OV, O'Dell LE (2010) Nicotine withdrawal produces a decrease in extracellular levels of dopamine in the nucleus accumbens that is lower in adolescent versus adult male rats. Synapse 64(2):136-145.

Parrott AC, Garnham NJ (1998) Comparative mood states and cognitive skills of cigarette smokers, deprived smokers and nonsmokers. Hum Psychopharmacol 13:367-376.

Paterson NE, Froestl W, Markou A (2004) The GABA B receptor agonists baclofen and CGP44532 decreased nicotine self-administration in the rat. Psychopharmacology (Berl) 172(2):179-186.

Pellow S, Chopin P, File SE, Briley M (1985) Validation of open:closed arm entries in an elevated plusmaze as a measure of anxiety in the rat. J Neurosci Methods 14:149-167.

Picciotto MR, Brunzell DH, Caldarone BJ (2002) Effect of nicotine and nicotinic receptors on anxiety and depression. Neuroreport 13(9):1097-1106.

Picciotto MR, Corrigall WA (2002) Neuronal systems underlying behaviors related to nicotine addiction: neural circuits and molecular genetics. J Neurosci 22:3338-3341.

Pomerleau OF (1986) Nicotine as a psychoactive drug: anxiety and pain reduction. Psychopharmacol Bull 22(3):865-869. 
Rada P, Jensen K, Hoebel BG (2001) Effects of nicotine and mecamylamine-induced withdrawal on extracellular dopamine and acetylcholine in the rat nucleus accumbens. Psychopharmacology (Berl) 157(1):105-110.

Rehni AK, Singh TG, Arora S (2012) SU-6656, a selective Src kinase inhibitor, attenuates mecamylamineprecipitated nicotine withdrawal syndrome in mice. Nicotine Tob Res 14(4):407-414.

Rubinstein M, Mogil JS, Japo'n M, Chan EC, Allen RG, Low MJ (1996) Absence of opioid stress-induced analgesia in mice lacking beta-endorphin by site-directed mutagenesis. Proc Natl Acad Sci USA 93:39954000 .

Sandoval MR, Palermo-Neto J (1985) Central nervous system supersensitivity and withdrawal from longterm treatment with barbital. Neuropharmacology 24(12):1247-1251.

SENASA. (Resolución 617/2002): Requisitos, condiciones y procedimientos para la habilitación técnica de laboratorios que posean bioterios de producción, mantenimiento y local de experimentación.

Simonin F, Valverde O, Smadja C, Slowe S, Kitchen I, Dierich A, Le Meur M, Roques BP, Maldonado R, Kieffer BL (1998) Disruption of the kappa-opioid receptor gene in mice enhances sensitivity to chemical visceral pain, impairs pharmacological actions of the selective kappa-agonist U-50,488H and attenuates morphine withdrawal. EMBO J 17:886-897.

Spano MS, Fattore L, Fratta W, Fadda P (2007) The GABA receptor agonist baclofen prevents heroininduced reinstatement of heroin-seeking behavior in rats. Neuropharmacology 52(7):1555-1562.

Stolerman IP, Jarvis MJ (1995). The scientific case that nicotine is addictive. Psychopharmacology (Berl) 117:2-10.

Toll BA, White M, Wu R, Meandzija B, Jatlow P, Makuch R, O'Malley SS (2010) Low-dose naltrexone augmentation of nicotine replacement for smoking cessation with reduced weight gain: a randomized trial. Drug Alcohol Depend 111(3):200-206.

Tome AR, Izaguirre V, Rosario LM, Cena V, Gonzalez-Garcia G (2001) Naloxone inhibits nicotine-induced receptor current and catecholamine secretion in bovine chromaffin cells. Brain Res 903:62-65.

Trigo JM, Zimmer A, Maldonado R (2009) Nicotine anxiogenic and rewarding effects are decreased in mice lacking beta-endorphin. Neuropharmacology 56:1147-1153.

Valverde O, Fournie-Zaluski MC, Roques BP, Maldonado R (1996) The CCKB antagonist PD-134,308 facilitates rewarding effects of endogenous enkephalins but does not induce place preference in rats. Psychopharmacology (Berl) 123(2):119-126.

Varani AP, Balerio GN (2012) GABAB receptors involvement in the effects induced by nicotine on anxietyrelated behaviour in mice. Behav Pharmacol 65:507-513.

Varani AP, Moutinho LM, Bettler B, Balerio GN (2012) Acute behavioural responses to nicotine and nicotine withdrawal syndrome are modified in GABA(B1) knockout mice. Neuropharmacology 63:863-872.

Varani AP, Moutinho LM, Calvo M, Balerio GN (2011) Ability of baclofen to prevent somatic manifestations and neurochemical changes during nicotine withdrawal. Drug Alcohol Depend 119:5-12. 
Villas Boas GR, Zamboni CG, Peretti MC, Correia D, Rueda AV, Camarini R, Brunialti-Godard AL, Boerngen-Lacerda $\mathrm{R}$ (2012) $\mathrm{GABA}_{(\mathrm{B})}$ receptor agonist only reduces ethanol drinking in light-drinking mice. Pharmacol Biochem Behav 102(2):233-240.

Watkins SS, Stinus L, Koob GF, Markou A (2000) Reward and somatic changes during precipitated nicotine withdrawal in rats: centrally and peripherally mediated effects. J Pharmacol Exp Ther 292(3):1053-1064. 
3 Fig 1 . Baclofen ( $3 \mathrm{mg} / \mathrm{kg}$, ip) blocked the rewarding properties induced by nicotine. The effect of baclofen 4 (BAC; 1, 2 and $3 \mathrm{mg} / \mathrm{kg}$; i.p.) on the rewarding properties induced by nicotine hydrogen tartrate salt (NIC; $0.5 \mathrm{mg} / \mathrm{kg}$, s.c.) in the place conditioning paradigm was investigated in mice. Results are represented as the difference between post-conditioning and pre-conditioning time spent in the drug-paired compartment. BAC or vehicle ( $\mathrm{VEH}, 0.9 \% \mathrm{NaCl}$ ) were administered $45 \mathrm{~min}$ before $\mathrm{NIC}$ or saline (SAL, $0.9 \% \mathrm{NaCl}$ ) injection during the conditioning phase. Data are expressed as mean \pm SEM ( $n=12-18$ mice for each group). Statistical analysis was performed using two-way ANOVA with chronic treatment (SAL or NIC) and acute treatment (VEH or BAC) as between-subjects factors of variation, followed by Fisher's post-hoc test.

$p<0.001$ when compared to VEH group. 坛动 $p<0.001$ comparisons between similar groups receiving SAL or NIC.

Fig 2. Baclofen (3 $\mathrm{mg} / \mathrm{kg}$, ip) prevented the somatic expression of naloxone-precipitated nicotine withdrawal. Counted (wet-dog shakes and paw tremor) and checked (body tremor, genital licks, ptosis, teeth chattering and piloerection) somatic signs of withdrawal were observed during $30 \mathrm{~min}$ immediately after naloxone (3 mg/kg, s.c.) administration. Baclofen (BAC; 1, 2 and $3 \mathrm{mg} / \mathrm{kg}$; i.p.) or vehicle (VEH, $0.9 \%$ $\mathrm{NaCl}$ ) were administered $45 \mathrm{~min}$ before withdrawal. A global withdrawal score was calculated for each animal as described in the methods. Data are expressed as mean \pm SEM $(n=10-14$ mice for each group). Statistical analysis was performed using two-way ANOVA with chronic treatment (saline, SAL, $0.9 \% \mathrm{NaCl}$ or nicotine hydrogen tartrate salt, NIC, $25 \mathrm{mg} / \mathrm{kg} / \mathrm{day}$ ) and acute treatment (VEH or BAC) as betweensubjects factors of variation, followed by Fisher's post-hoc test. $\star \quad p<0.05, \quad \star \star \star \quad p<0.001$ when compared to VEH group. is $p<0.05$, 施访 $p<0.001$ comparisons between similar groups receiving chronic SAL or NIC.

Fig 3. Baclofen (3 mg/kg, ip) prevented the anxiety-like effects associated with naloxone-precipitated nicotine (NIC) withdrawal. Percentage of entries into (A) and time spent in the open arms of withdrawal were observed during $15 \mathrm{~min}$ immediately after naloxone (3 mg/kg, s.c.) administration. Baclofen (BAC; 1 , 2 and $3 \mathrm{mg} / \mathrm{kg}$; i.p.) or vehicle ( $\mathrm{VEH}, 0.9 \% \mathrm{NaCl}$ ) were administered $45 \mathrm{~min}$ before withdrawal. Data are expressed as mean \pm SEM ( $\mathrm{n}=8$-10 mice for each group). Statistical analysis was performed using two-way ANOVA with chronic treatment (saline, SAL, $0.9 \% \mathrm{NaCl}$ or nicotine hydrogen tartrate salt, NIC, 25 $\mathrm{mg} / \mathrm{kg} / \mathrm{day}$ ) and acute treatment ( $\mathrm{VEH}$ or BAC) as between-subjects factors of variation, followed by

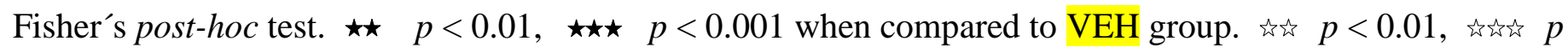
$<0.001$ comparisons between similar groups receiving chronic SAL or NIC. 
1 Fig 4. Baclofen (BAC, $2 \mathrm{mg} / \mathrm{kg}$, i.p.) did not modify the dysphoric manifestations of naloxone-precipitated 2 nicotine (NIC). Naloxone (NLX, $0.12 \mathrm{mg} / \mathrm{kg}$, s.c.) induced nicotine withdrawal place aversion score and was 3 calculated as the difference between the time (s) spent in the withdrawal associated compartment during the 4 post-conditioning and the pre-conditioning phase (see Materials and methods for details). Data are expressed 5 as mean \pm SEM ( $\mathrm{n}=10-14$ mice for each group). $\star p<0.05$ compared to vehicle-saline (VEH-SAL) group 6 (Fisher's post hoc test). 
Table 1 Baclofen prevents the somatic expression of naloxone-precipitated nicotine

withdrawal

\begin{tabular}{|c|c|c|c|c|c|c|c|c|c|c|c|c|c|}
\hline \multirow[b]{3}{*}{ Sign } & \multicolumn{6}{|c|}{ Two-way ANOVA } & \multicolumn{7}{|c|}{ Fisher's post-hoc test } \\
\hline & \multicolumn{2}{|c|}{\begin{tabular}{|c|}
$\begin{array}{c}\text { Chronic } \\
\text { treatment }\end{array}$ \\
\end{tabular}} & \multicolumn{2}{|c|}{ Acute treatment } & \multicolumn{2}{|c|}{ Interaction } & $\begin{array}{c}\text { Sal-Sal vs Nic- } \\
\text { Sal } \\
\end{array}$ & $\begin{array}{c}\text { Sal-BAC }{ }_{1} \text { vs Nic- } \\
\text { BAC }_{1} \\
\end{array}$ & $\begin{array}{l}\text { Nic-Sal vs Nic- } \\
\text { BAC }_{1} \\
\end{array}$ & $\begin{array}{c}\text { Sal-BAC } 2 \text { vs Nic- } \\
\text { BAC }_{2} \\
\end{array}$ & $\begin{array}{c}\text { Nic-Sal vs Nic- } \\
\text { BAC }_{2} \\
\end{array}$ & $\begin{array}{c}\text { Sal-BAC }{ }_{3} \text { vs Nic- } \\
\mathrm{BAC}_{3} \\
\end{array}$ & $\begin{array}{c}\text { Nic-Sal vs Nic- } \\
\mathrm{BAC}_{3} \\
\end{array}$ \\
\hline & \begin{tabular}{|c}
$\mathrm{F}(1,84$ \\
) \\
\end{tabular} & \begin{tabular}{|c|}
$P-$ \\
value \\
\end{tabular} & $\begin{array}{c}\mathrm{F}(3,84 \\
) \\
\end{array}$ & $\begin{array}{c}P- \\
\text { value }\end{array}$ & $\begin{array}{c}\mathrm{F}(3,84 \\
) \\
\end{array}$ & $\begin{array}{c}P- \\
\text { value }\end{array}$ & P-value & $P$-value & $P$-value & $P$-value & P-value & $P$-value & $P$-value \\
\hline Paw tremor & 74.3 & $\begin{array}{c}< \\
0.001\end{array}$ & 25.8 & $\begin{array}{c}< \\
0.001\end{array}$ & 19.6 & $\begin{array}{c}< \\
0.001\end{array}$ & $<0.001$ & $<0.001$ & NS & NS & $<0.001$ & NS & $<0.001$ \\
\hline Body tremor & 47.8 & $\begin{array}{c}< \\
0.001\end{array}$ & 8.8 & $\begin{array}{c}< \\
0.001\end{array}$ & 7.9 & $\begin{array}{c}< \\
0.001\end{array}$ & $<0.001$ & $<0.05$ & NS & $<0.05$ & NS & NS & $<0.001$ \\
\hline Teeth chattering & 49.0 & $\begin{array}{c}< \\
0.001\end{array}$ & 22.2 & $\begin{array}{c}< \\
0.001\end{array}$ & 21.4 & $\begin{array}{c}< \\
0.001\end{array}$ & $<0.001$ & $<0.001$ & $<0.05$ & NS & $<0.001$ & NS & $<0.001$ \\
\hline Genital licks & 4.1 & NS & 4.1 & $<0.01$ & 0.8 & NS & - & - & - & - & - & - & - \\
\hline Wet-dog shakes & 5.6 & $<0.05$ & 3.4 & $<0.05$ & 2.9 & $<0.05$ & $<0.05$ & NS & NS & NS & $<0.05$ & NS & $<0.05$ \\
\hline Scratches & 10.6 & $<0.01$ & 2.1 & NS & 1.8 & $\mathrm{NS}$ & - & - & - & - & - & - & - \\
\hline Ptosis & 2.8 & NS & 0.8 & NS & 0.2 & NS & - & - & - & - & - & - & - \\
\hline Piloerection & 11.2 & $\begin{array}{c}< \\
0.001\end{array}$ & 0.1 & NS & 0.3 & NS & - & - & - & - & - & - & - \\
\hline $\begin{array}{l}\text { Locomotor } \\
\text { activity }\end{array}$ & 0.9 & NS & 0.3 & NS & 0.3 & NS & - & - & - & - & - & - & - \\
\hline Global score & 127.3 & $\begin{array}{c}< \\
0.001\end{array}$ & 35.1 & $\begin{array}{c}< \\
0.001\end{array}$ & 27.1 & $\begin{array}{c}< \\
0.001\end{array}$ & $<0.001$ & $<0.001$ & NS & NS & $<0.001$ & NS & $<0.001$ \\
\hline
\end{tabular}

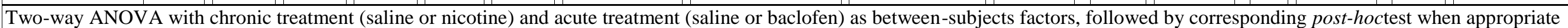
(Fisher's test). To simplify the table, the comparison between Sal-Sal and Sal-Bac is not shown, since it was not significant in any case. See Materials and methods for details. 


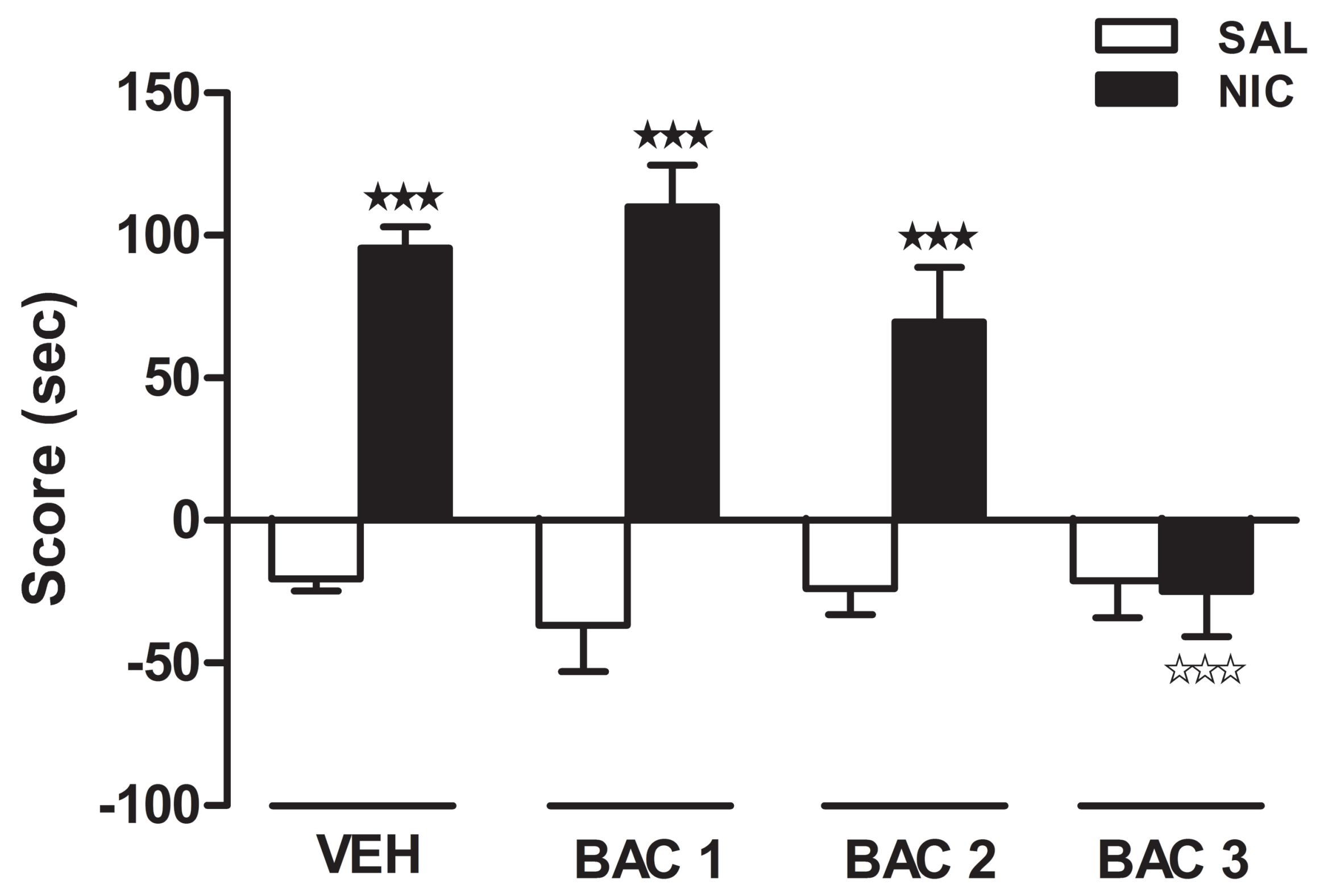



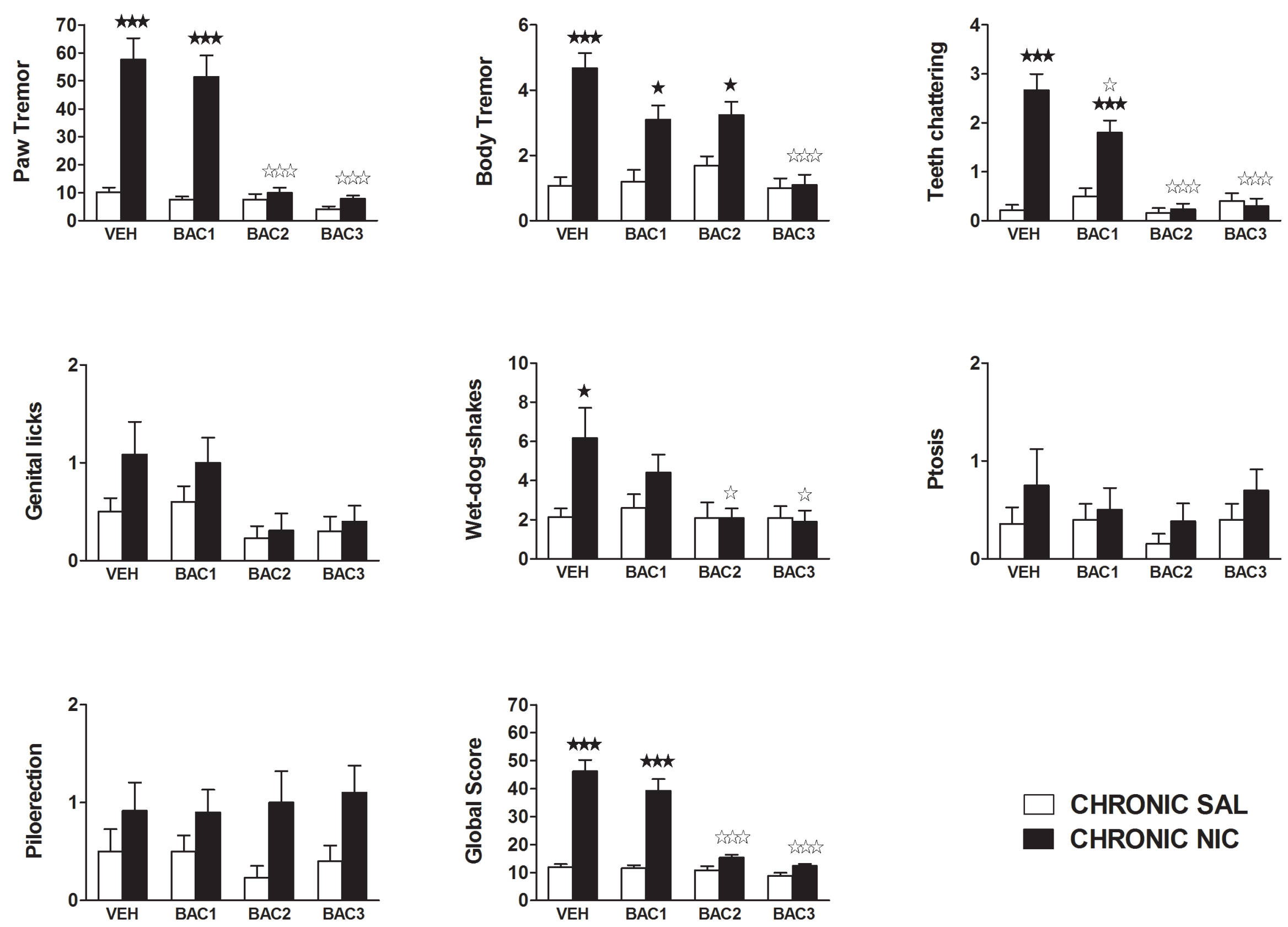

$\square$ CHRONIC SAL - CHRONIC NIC 
A

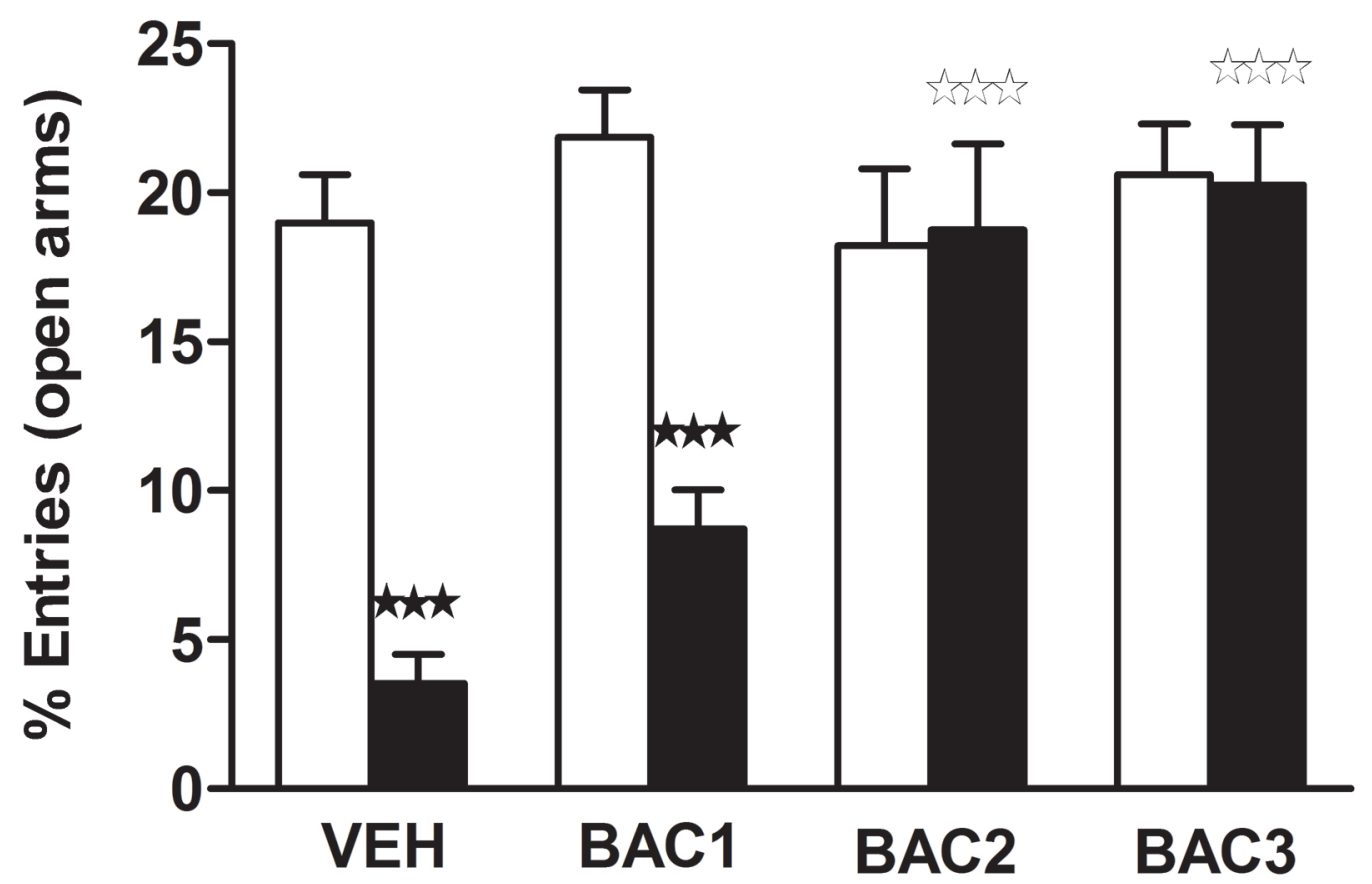

B

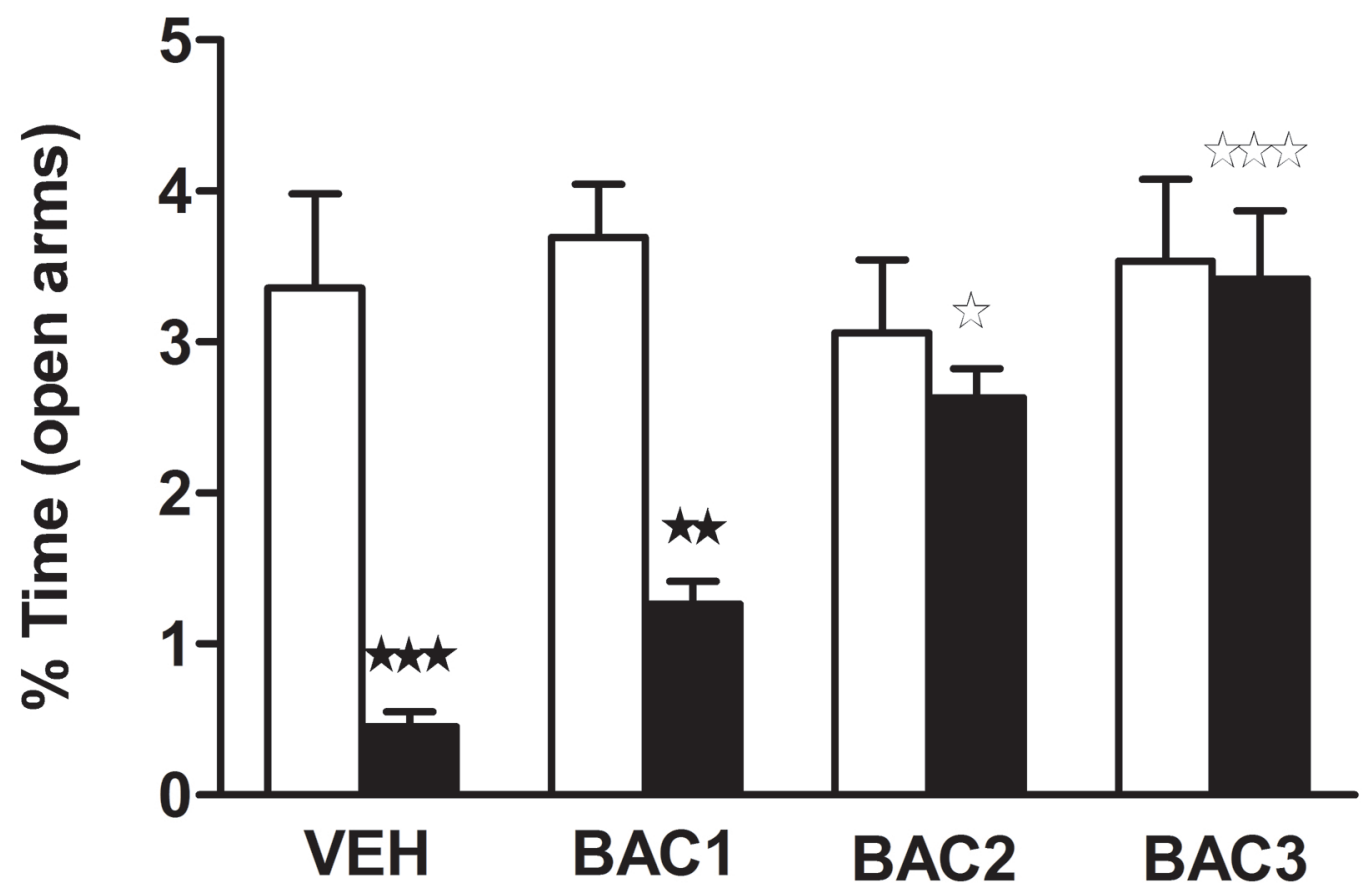

$\square$ CHRONIC SAL

$\square$ CHRONIC NIC 


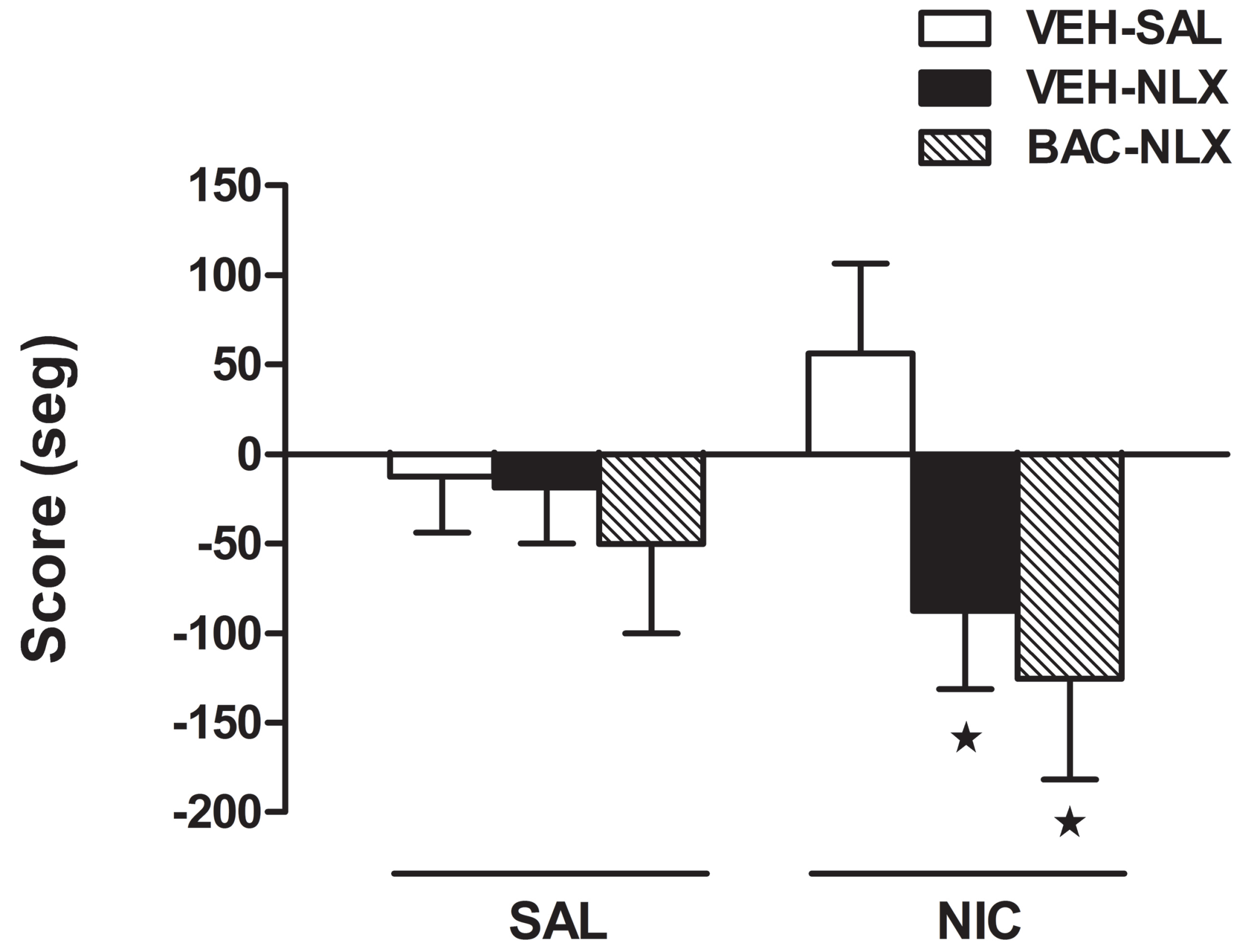

